\title{
Constitutionality of the Former Ex-Convict as Election Participants of Regional Heads
}

\author{
$1^{\text {st }}$ M. Guntur Hamzah \\ The Constitutional Court of the \\ Republic of Indonesia \\ Jalan Medan Merdeka Barat Number \\ 6, Jakarta Pusat - 10110 \\ *guntur@mkri.id
}

\author{
$2^{\text {nd }}$ Wilma Silalahi \\ The Constitutional Court of the \\ Republic of Indonesia \\ Jalan Medan Merdeka Barat Number \\ 6, Jakarta Pusat - 10110
}

\begin{abstract}
A country would be in peace and prosperity and grow well, if the leader leads with integrity and wisefulness. Therefore, clear and firm arrangements are needed in selecting candidates for regional heads who are exconvicts. And the task of the state is in accordance with the mandate of the Pancasila and the 1945 Constitution, which is to form an Indonesian Government that protects all the people of Indonesia. In choosing its regional head, it must be carried out by way of democratic and civilized elections through the widest possible participation of the people. This is according to the provisions stipulated in Article 18 paragraph (4) of the 1945 Constitution. Every citizen has the same right to be elected and elect representatives who will sit in the administration both at the central and regional levels. Thus, all citizens who have fulfilled the requirements in an election, are obliged to use their political contributions in order to fulfill a quality election. For this reason, the elections must be done with quality. The state also has a role and obligation as the holder of fulfilling human rights. Through The Decision of the Constitutional Court Number 56/PUU-XVII/2019, dated December 11, 2019, firmly regulates the constitutionality of norms governing the requirements of regional head candidates as far as the exinmates regulated in the norm provisions of Article 7 paragraph (2) letter $g$ of Law Number 10 of 2016. To produce a qualified, honest, clean, and integrited leader, it is proper to have high quality and tested morals. Prospective regional head who is a former convict must be able to prove himself and give confidence to the community that he has changed.
\end{abstract}

Keywords-ex-convict leader, election, regional head candidate, Constitutional Court Decision Number 56/PUUXVII/2019, Law Number 10 of 2016.

\section{INTRODUCTION}

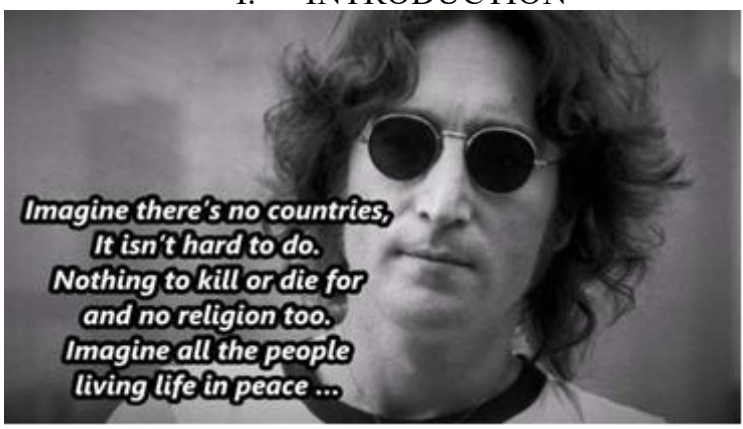

Lyrics from a John Lennon song "Imagine". ${ }^{12}$ In the song Imagine it is implied that without a country, there will be peace in living life, there is no reason to kill and be killed. Thus, the leader must also be able to prove that the country can create peace and prosperity for its citizens. Creating a strong state of a strong individual. ${ }^{3}$ Talking about the country, can not be separated from talks about $\mathrm{d}^{\S}$ emocracy and the government system. All countries definitely want to live in peace, of course no killing. ${ }^{4}$ Therefore, every country needs leaders who are reliable, wise, and can bring their country towards prosperity. Countries in general, in choosing their leaders, they certainly are not free of problems. The people certainly wants their leader to be able to bring improvement and prosperity to his country. A leader must really be able to show the nature of a leader and can carry out their duties and obligations. A leader must be able to behave wisely towards the country and his people. Therefore, a leader carries a very heavy task.

In this paper the author will examine how the Constitutional Court as an institution that is given the authority to examine the law against the 1945 Constitution of the Republic of Indonesia, providing appropriate treatment for candidates for regional heads. Therefore, this study uses a normative approach with a postpositivism paradigm, that the formation of a statutory regulation must be in accordance with the mandate of the Pancasila and the 1945 Constitution as the highest law in the statutory regulatory system, using normative juridical ${ }^{5}$ 
research methods or according to Wignjosoebroto is doctrinal research, ${ }^{6}$ that research that uses positivist legis, which states that law is identical with written norms created and promulgated by authorized institutions or officials. In addition, in this conception, the law is seen as a normative system that is autonomous, closed, and independent of people's lives. Satjipto Rahardjo said that this research is looking at the law as an abstract regulation, its attention will be on a truly autonomous institution, which we can discuss as a separate subject, regardless of its relation to matters outside the regulation. Its concentration will lead to the normative method, and in accordance with the analysis discussion, this method is called normative analysis. ${ }^{\text {? }}$

\section{A. Government}

\section{DISCUSSION/ANALYSIS}

Government systems used by countries can be distinguished, among others: ${ }^{8}$

1. Monarchy

Also called the royal government system ruled by a king without any limitation of tenure (also called "for life / all his life"). This government system is divided into 3 forms, namely: Absolute Monarchy, Parliamentary Monarchy, and Constitutional Monarchy. ${ }^{9}$ And the mentioning of heads of state who adheres to this system also varies, such as "The One in Agong-Pertong" (Malaysia), "King \& Queen" (Thailand, Saudi Arabia, Great Britain, Morocco, and Spain), "Pope" (Vatican City), "Sultan" (Brunei and Oman), "Emperor" (Japan), etc. Whereas in the Special Region of Yogyakarta also serving as Governor is Sri Sultan Hamengkubuwono, so it can be interpreted that the Special Region of Yogyakarta also adheres to the Monarchy system.

2. Democracy

Democratic government systems are based on popular power or popular sovereignty. All citizens in the country in this system have equal rights in decision making that can change their lives. The democratic system in electing its leaders can be implemented either directly or indirectly by the people through its representatives. One of the principles known in a democratic country is the principle of Trias Politica, which divides the country's political power into three, namely the legislative, executive, and judiciary. Countries that embrace this system include: Indonesia and the United States.

3. Autocracy

Is a system of government where power is held by one person. The country that adopted this system but has now disappeared is Germany, during the reign of Nazism and Italy, during the time of Fascism. an autocratic leader keeps tight control over group decisions and activities. The autocratic leader determines all policies, techniques, and activity steps and dictates the particular work tasks and work companions of each member. The autocratic leader tends to be personal in his or her praise and criticism of the work of each member but remains aloof from active group participation. ${ }^{10}$ White and Lippitt (1960) identified the autocratic leader with the authoritarian leader. ${ }^{11}$

4. Oligarchy

It is a country whose political power is held by a small elite group from the community. The oligarchs compartmentalize communities based on wealth, family and military. This system was adopted by Russia during the Stalin regime. In Indonesian politics context, the existences of the oligarchy are strengthening as well as the flow of formal democracy. ${ }^{12}$ Oligarchy is a term that used by Plato to explain a government before democracy. Oligarchy is the government that ruled by some people. ${ }^{13}$ But in real term, political oligarchy is used to describe a government system that is controlled not just by several richest persons, but also interest groups that control the executive, legislative and judiciary power with their policy and decisions are mainly the upper half of society needs. ${ }^{14}$ Oligarchy is a system that the government is controlled by some rich and powerful persons for the interest of their groups. In Aristoteles ${ }^{15}$ thoughts, what they called as citizens of that era were about whom to recognize as citizens. Not everybody is a citizen. Children, female, foreigner, artisans and mechanics and all who does a public service works are not citizens. They already have their own rules. Citizens are limited to adult male, who have spare time to participate in public life. Jeffery A. Winters also admits that the term Oligarchy is a well-known term in political studies. This term is spread out from the ancient Greek era to the present time. In the international encyclopedia of social sciences, Oligarchy is defined as "a form of governance where powers are in the hands of small minorities." The term is taken from the Greek language "oligarchs" that means governance by a few, from the word oligoi (a little), and arkhein (ruling - to govern) ${ }^{16}$, oligarchy is a government ruled by some people. Oligarchy has a wealth of the ordinary or even wealthier than average rich. Or you can call it super-rich individuals. Their features in the political arena are based on the failure of a country in 
protecting their wealth from several threats, even if that threat comes from that country itself. ${ }^{17}$

Indonesia as an independent country consisting of an island nation, in addition to the head of the country (also called the President), each region also has a head of government in their respective regions. Because Indonesia as a democratic country, in choosing its head of state and head of region, implements by way of election, both directly and through representative institutions.

\section{B. Regional Head Elections}

Indonesia in carrying out its wheels of government must be in accordance with the mandate of the Pancasila and the 1945 Constitution, namely to form an Indonesian Government that protects all of the Indonesian people and all of Indonesia's blood spills and to advance public welfare, educate the nation's life, and participate in carrying out world order based on independence, eternal peace and social justice, the Indonesian National Independence was compiled in an Indonesian Constitution, which was formed in the composition of the Republic of Indonesia which sovereigns the people based on the Godhead of the Almighty, just and civilized Humanity, the Unity of Indonesia, and populistism which is led by wisdom in Consultative/Representative, and by realizing a social justice for all Indonesian people. ${ }^{18}$

Thus, sovereignty is in the hands of the people and implemented according to the Basic Law. So that in electing regional heads, carried out by way of democratic and civilized elections through broad participation of the people. This democratic election is not expressly regulated in the constitution. The provisions of Article 18 paragraph (4) of the 1945 Constitution states that, "Governors, Regents and Mayors respectively as heads of provincial, district and city regional governments shall be democratically elected". The meaning of being democratically elected is that regional head elections are held on the basis of direct, general, free, secret, honest and fair principles.

Thus, the election of regional heads and deputy regional heads is a means of implementing people's sovereignty in the provinces and/or districts/cities based on Pancasila and the 1945 Constitution of the Republic of Indonesia to elect Regional Heads and Deputy Regional Heads. ${ }^{19}$ According to Joko J. Prihantoro, the regional head election is a political recruitment, namely the selection of the people against figures who nominate themselves as regional heads, both the Governor/Deputy Governor and the Regent/Deputy Regent or Mayor/Deputy Mayor. ${ }^{20}$ Citizens have the same right to be elected and elect representatives who will sit in government both at the center and in the regions. So that all citizens who have fulfilled the requirements in an election, are obliged to use their political contributions to achieve quality elections. Regional head elections, which is one of the ways in electing regional heads must also be carried out with quality regional head elections. ${ }^{21}$ With the support and participation of citizens to produce quality elections, there will be the intent and purpose of the elections.

As a democratic country, the implementation of the elections by the Indonesian people, carried out based on democratic principles and in accordance with the principles of the elections. The implementation of the elections as a form of people's sovereignty is carried out in the provinces and districts/cities, which since 2015 have been carried out directly by the people to elect the governor and deputy governor, regent and deputy regent, and/or mayor and deputy mayor. The people have the same right to participate in determining the representatives who will lead in their area. Likewise the people have the same right to participate as participants in the elections. Therefore, the implementation of the elections must be in accordance with Pancasila and the 1945 Constitution, that is, there should not be discriminatory treatment to vote and be elected in the elections.

The people are given the maximum freedom to determine their voting rights to the trusted representative. Whoever is chosen by the people, is the political right of the people in determining their choices. And all citizens who meet the requirements as regulated in the legislation are entitled to submit themselves and can become participants in the elections. So it is very important the role and responsibility of the government in providing political education to its citizens.

\section{Ex-convict leaders}

Every citizen has the same right to vote and be elected in an election without discrimination. Likewise, the candidates for state leaders and regional head candidates cannot be limited to nominating themselves or as voters in an election. A number of countries have leaders who are ex-convicts for various reasons and problems. But history proves that, thrown in a hotel without prodeo didn't turn out to be the end of world leaders. Precisely this is the beginning of a struggle and a larger life journey they face. World leaders who have been imprisoned before finally succeeding in becoming leaders in countries, namely: ${ }^{22}$

\section{Benazir Bhutto}

Is the first woman who was democratically elected to be Prime Minister in a Muslim- majority country, Pakistan. Bhutto is the daughter ${ }^{23}$ of former Prime Minister, Zulfikar Ali Bhutto, founder of the Pakistan People's Party (PPP). ${ }^{24}$ In 1977, after finishing school in England (1973-1977), Bhutto was immediately sentenced to house arrest. The decision was taken after his father was coup by General Zia ul-Haq. Through Zia's orders, Ali Bhutto was executed by hanging, causing international outcry. In addition to the execution of Zulfikar Ali Bhutto, 
Benazir and his sister on April 4, 1979 were thrown into prison and not allowed to attend his father's funeral. In prison, Benazir instead made PPP win in Pakistan's local elections. This victory made General Zia postpone the national elections and move prisoners from Karachi to the central prison in Larkana.

On December 11, 1981, Bhutto finally received house arrest status. In 1984, after serving time in prison and at home, Bhutto and his family were allowed to leave Pakistan to go to England in exile while recovering their health. After a long journey, in 1993, Bhutto was elected Prime Minister of Pakistan.

\section{Fidel Castro}

The former Cuban President began his political journey in 1947. The social injustice he witnessed led him to go to the Dominican Republic. There Castro joined in a movement to overthrow dictator Rafael Trujillo. The attempt failed, but Castro's spirit of reform became even more fiery. From the Dominican Republic, Castro headed to Bogota to take part in antigovernment riots. Upon his return to Cuba, Castro joined Partido Ortodoxo, led by presidential candidate Eduardo Chibas. The party lost the 1948 election. The defeat triggered Castro to expose the crime and corruption committed by the then Cuban leader, General Fulgencio Batista.

Seeing Batista increasingly acting arbitrarily, together with members of the Orthodoxo Partido, Castro formed "The Movement" whose aim was to oppose General Batista's power. On July 26, 1953, Castro and 159 of his supporters attacked the military barracks outside the Santiago de Cuba area. But the attack failed. Castro, along with some of his colleagues, were arrested. Sentence for 15 years imposed on Castro. However, the wheel of history sided with Castro, despite being a convict, in 1976, Aisyah Saipuddin, Pasang Surut Hubungan Sipil-Militer Dalam Perpolitikan Pakistan, Jurnal Indpendence, Th. 1, Vol. 1, Januari-April 2013, pp. 64. Castro became the 17th President of Cuba.

\section{Xanana Gusmao}

Xanana, a former journalist who had the political will to free Timor Leste, decided to join the Social Democrat Association (ASDT) which was the forerunner of the Revolutionary Front for an Independent Timor-Leste (FRETILIN). In 1983, Xanana led formal negotiations with Indonesia to discuss a ceasefire. Xanana is known as a guerilla. Xanana was also jailed in a prison. Cipinang as a political prisoner. On 7 September 1999, Xanana was completely free, where on 10 February 1999 he was placed under house arrest in Salemba, Central Jakarta. After independence, Xanana served as PM.

\section{Nelson Mandela}

On 12 June 1964, South Africa's anti-apartheid fighter, Nelson Mandela was sentenced to life in prison. Mandela at the time led the Africal National Congress (ANC) was found guilty of sabotaging the government, which was dominated by whites even though the majority of South Africans were black. Although sentenced for life, Mandela was finally released after 27 years in jail in 1990. Four years later, Mandela was elected as the President of
South Africa who shined until he won the Nobel Peace Prize.

\section{Soekarno}

Is the Father of the Indonesian Nation, the Proclaimer. Sukarno was thrown into prison on December 29, 1929, on the Benceuy Street, Bandung. Sukarno was detained for approximately eight months. After his release, Sukarno continued his independence struggle and declared independence on August 17, 1945.

E. Requirements for Former Prisoners as Regional Head Candidates Based on Constitutional Court Decisions

The country has a role and obligation as the holder of the fulfillment of human rights, therefore, the country carries out its duties to its citizens, including: ${ }^{25}$ (1) the country must acknowledge (to admit), to uphold, to protect, ${ }^{26}$ to advance, to respect, ${ }^{27}$ and to fulfill ${ }^{28}$ the constitutional rights of its citizens. So that the country must respect and carry out its roles and duties, especially in the democratic elections which will soon be held.

The country must provide guarantees to its citizens in terms of election, both as participants and as voters, so that the citizens' constitutional rights are not harmed. Therefore, the simultaneous regional election in 2020 is the fourth regional head election which was originally planned to be held on September 23rd, 2020, but due to the global pandemic/disaster Corona Virus Disease 2019 (Covid-19) resulted in plans to carry out regional head elections experiencing delays. The spread of Covid-19 which was declared a global pandemic by the World Health Organization which occurred in most countries around the world, including in Indonesia, and has caused many casualties and shows an increase over time and has been determined as a national disaster.

In the context of overcoming the spread of Covid-19, which is a national disaster and for the sake of prioritizing national health and not in conflict with human rights, the government adopted a policy to postpone the stages of the election of governors and deputy governors, regents and deputy regents, as well as mayors and deputy mayors simultaneously in 2020, the election of governors and deputy governors, regents and deputy regents, and mayors and deputy mayors will continue to take place in a democratic and quality manner and to maintain domestic political stability. Through Government Regulation in Lieu of Law Number 2 of 2020 concerning the Third Amendment to Law Number 1 of 2015 Regarding the Establishment of Government Regulation in Lieu of Law Number 1 of 2014 Regarding the Election of Governors, Regents and Mayors to Become Acts, Statute Book of the Republic Indonesia Year 2020 Number 128, Supplement to the Country Gazette of the Republic of Indonesia Number 6512, hereinafter referred to as Perpu 2/2020, the implementation of continued Elections or simultaneous 
Elections $^{29}$ will be held simultaneously in December 2020, with the provisions if the non-natural disaster ends, but if the non-natural disaster has not ended so that the collection concurrent votes cannot be implemented, will be rescheduled.

The simultaneous regional head elections, which are planned to be held in December 2020, will take place in 270 electoral districts: ${ }^{30}$ in 9 provinces for governor election, in 224 districts for the election of regents, and in 37 cities for the election of mayors the constitutional rights of every citizen must be guaranteed. With regard to the implementation of the 2020 elections, the Constitutional Court, through its decision, gave freedom of constitutional rights to ex-convicts to nominate themselves as candidates for election, but with conditions that explicitly regulate them, except for former drug convicts and sexual crimes against children. ${ }^{31}$

Thus, the Constitutional Court's Decree has given room for ex-convicts to adapt to the community at least five years after the prisoner has served his sentence. The five-year period according to the Decision of the Constitutional Court Number 56/PUU-XVII/2019, dated December 11, 2019, submitted by Indonesia Corruption Watch (ICW) and the Association for Elections and Democracy (Perludem), explicitly regulates the constitutionality of the norms governing the requirements regional head candidates as far as the former convict is regulated in the provisions of the norm Article 7 paragraph (2) letter $g$ of Law Number 10 of 2016 as long as they are not interpreted to have passed the period of 5 years after the former convicted has finished serving a prison sentence based on a court decision that already has permanent legal force; thus Article 7 paragraph (2) letter $g$ of Law Number 10 of 2016 reads: "Candidates for Governor and Candidates for Deputy Governor, Candidates for Regent and Candidates for Deputy Regent, and Candidates for Mayor and Deputy Mayor as referred to in paragraph (1) must meet the following requirements: g. (i) have never been a convict based on a court decision that has obtained permanent legal force due to a criminal offense that is threatened with imprisonment of 5 years or more, except for the convicted person who committed an act of negligence and political crime in the sense of an act declared as criminal acts in positive law only because the perpetrators have political views that are different from the regime in power; (ii) for ex-convicts, has passed a period of 5 years after the former convicted has finished serving a prison sentence based on a court decision that has permanent legal force and honestly or publicly announces his true background as a former convict; and (iii) not as a perpetrator of recurrent crimes.

Article 7 paragraph (2) letter g of Law Number 10 of 2016, in consideration of the Constitutional Court of the Republic of Indonesia, The Court has repeatedly affirmed its stance, among which, decision of the Constitutional
Court Number 14-17/PUU-V/2007, dated December 11, 2007 expressly regulates the requirements "Never been sentenced to prison based on a court decision that has permanent legal force for committing an offense threatened with imprisonment of 5 years or more". These requirements do not contradict the 1945 Constitution as long as they do not include criminal offenses born due to minor negligence (culpa levis) and criminal offenses due to certain political reasons and taking into account the nature of certain positions which require different requirements. This was confirmed also by the Constitutional Court Decision Number 4/PUU-VII/2009, dated March 24, 2009, Constitutional Court Decision Number 120/PUU-VII/2009, dated April 20, 2010, Constitutional Court Decision Number 71/PUUXIV/2016, dated July 19, 2017, and Constitutional Court Decision Number 56/PUU-XVII/2019, dated December $11,2019$.

In the decisions of the Constitutional Court above, have the same spirit, which determines the conditions for someone who will fill a public position or political position which is filled out by election based on Article 12 letter $g$ and Article 50 paragraph (1) letter $g$ of Law Number 10 of 2008 and Article 58 letter f of Law Number 12 of 2008 is a conditionally unconstitutional conditional legal norm. These legal norms are unconstitutional if the following conditions are not met: (1) does not apply to elected public offices as long as an additional criminal is not imposed in the form of revocation of the right to vote by a court decision that has permanent legal force; (2) valid for a limited period of 5 years after the former convict has finished serving a prison sentence based on a court decision that has permanent legal force; (3) honesty and openness regarding his background as a former convict; (4) not as a perpetrator of recurring crimes.

The court is a reasonable time as a proof of the exconvicts who have good behavior and do not repeat criminal acts as the purpose of the penalties regulated in Act Number 12 of 1995 concerning Correctional Facilities. If an ex-convict is restricted from nominating himself as a regional head candidate, according to the Constitutional Court Decision Number 42/PUU$\mathrm{XIII} / 2015$, then it is equally meaningful that the Law has given additional penalties to those concerned while the 1945 Constitution has prohibited the application of discrimination to all its citizens. Former convicts who have finished serving their sentence and are out of prison are basically according to the Court are people who have regretted their actions, have repented, and promised not to repeat their actions. Thus, a former convict who has repented is not appropriate if given another sentence by the Law as specified in Article 7 letter $g$ of Law Number 8 of 2015.

With regard to the four conditions stipulated in the Constitutional Court Decision Number 4/PUU-VII/2009, it cannot be excluded because it is an inseparable unit. And this is not an alternative condition but a cumulative condition that is related to one another. And this is also intended to produce leaders who are qualified, honest, clean, and have integrity. 


\section{CONCLUSION}

To produce a good quality, honest, clean, and integrited leader, it is proper to have high quality and tested morals as well as the most important one, integrity. Prospective regional head who is a former convict must be able to prove himself and give confidence to the community that he has changed. Thus the four conditions stipulated in the Constitutional Court Decision Number 4/PUU-VII/2009 constitute an inseparable unity, to provide legal certainty to the public, the purpose of the election is achieved, creating qualified, honest and integrity elections and producing chief leaders areas that are clean, honest and have integrity. This is also confirmed by the Constitutional Court Decision Number 56/PUU-XVII/2019, dated December 11, 2019. On the issue of the participation of ex-convicts in the elections, especially the 2020 elections which are planned to be held simultaneously in December 2020, the General Election Commission (KPU) must also prepare and adjust the Election Commission Regulation (PKPU) with the Constitutional Court Decree Number 56/PUU-XVII/2019.

Thus, the thing that accommodates the prohibition of ex-convicts from running for regional head election is because the political rights (of ex-convicts) can only be revoked by a court ruling. As a democratic country that upholds the constitutional rights of each of its citizens, Indonesia gives freedom to ex-convicts to use their constitutional rights as candidates for regional heads in the election of governors and deputy governors, regents and deputy regents, and / or mayors and deputy mayors as long as they meet the requirements as required. has been decided in Decision of the Constitutional Court Number 4/PUU-VII/2009 and the constitutional rights cannot be reduced for any reason except by laws and court decisions that regulate it and have permanent legal force, and the government has the obligation to provide political education to all citizens, as well as regulations governing the election of governors, regents and mayors, need to be immediately improved and refined.

The Treatment that ex-convicts can take part in the nomination as a participant in the elections is constitutional. We can also see this from the history of world leaders who were imprisoned before finally becoming leaders in their countries. Therefore, as long as they do not have personal interests, and the task of being a country leader or as a regional head is proof that they love their country and do their best for their country.

"The opportunity only comes once, if you are still given a second chance, make the best use of it properly and wisely, give respect to the community and show them that you are worthy of trust."

\section{REFERENCES} [Online].

[1] source:

https://www.youtube.com/watch?v=L6svOHFSAH8.

[2] Makmur Keliat, Agus Catur Aryanto, Cut Nury Hikmah, Hana Hanifah, Rizki Yuniarini, TanggungJawab Negara, (Jakarta: Friedrich-Ebert-Stiftung, Kantor Perwakilan Indonesia, Cetakan II, Juni 2016) pp. 32.

[3] Firdaus Zeta Abidin, Faktor Penyerangan Korea Utara terhadap Korea Selatan di Sekitar Pulau Yeonpyeong pada
Tahun 1999 dan 2002, Journal of International Relations, Volume 5, Nomor 4, 2019, pp. 653 [Online]. Available: https://ejournal-s1.undip.ac.id/index.php.jihi. Accesed:_August, 5,2020

[4] Bambang Sunggono, Metodologi Penelitian Hukum, (Jakarta: Raja Grafindo Persada, 1997) pp. 42

[5] Bentuk Pemerintahan Monarki/Kerajaan. [Online]. Available: https://jefrihutagalung.wordpress.com/2009/05/04/bentukpemerintahan-monarkikerajaan/. Accesed:_Jul. 2, 2020

[6] Undang-Undang Dasar Negara Republik Indonesia Tahun 1945.

[7] Peraturan Pemerintah Nomor 6 Tahun 2005 tentang Pemilihan, Pengesahan Pengangkatan, dan Pemberhentian Kepala Daerah dan Wakil Kepala Daerah sebagaimana telah diubah dengan Peraturan Pemerintah Nomor 49 Tahun 2008 tentang Perubahan Ketiga Atas Peraturan Pemerintah Nomor 6 Tahun 2005 Tentang Pemilihan, Pengesahan Pengangkatan, dan Pemberhentian Kepala Daerah dan Wakil Kepala Daerah.

[8] Hani Adhani, Sengketa Pilkada, Penyelesaian dari Mahkamah Agung ke Mahkamah Konstitusi, (Depok: PT. RajaGrafindo Persada, Cet. I, 2019) pp. 15.

[9] Sanghan Choi, Democratic Leadership: The Lessons of Exemplary Models for Democratic Governance, International Journal of Leadership Studies, Volume 2, Issue 3/2007.

[10] White, R. K., \& Lippitt, R. O. Autocracy and democracy: An experimental inquiry. New York: Harper \& Brothers, 1960.

[11] Muhammad Zulfan Hakim, Fajlurrahman Jurdi, Immature Politicians and Oligarchy As a Threat to Democracy, Fiat Justisia Jurnal Ilmu Hukum, Volume 11 Number 4, OctoberDecember 2017, pp. 344.

[12] Andreas Gerry Tuwo, Sukarno hingga Mandela, 5 Pemimpin Dunia Ini Pernah Dipenjara. [Online]. Available: https://www.liputan6.com/global/read/2945966/sukarno-hinggamandela-5-pemimpin-dunia-ini-pernah-dipenjara. Accesed: March 2, 2020.

[13] George Junus Aditjondro, Membedah Kembar Siam Penguasa Politik dan Ekonomi Indonesia, Jakarta: LP3ES, (2004), pp. 11.

[14] Winarno, Pemikiran Aristoteles Tentang Kewarganegaraan dan Konstitusi, Jurnal Humanika, 2015, pp. 21.

[15] Jeffrey A. Winters, "Oligarchy and Democracy", The American Interest Journal, 7 (2), (2011), pp. 1.

[16] Retno Kusniati, Integrasi Standar Perlindungan, Penghormatan, dan Pemenuhan HAM Dalam Tugas dan Fungsi Satuan Kerja Perangkat Daerah, Makalah disampaikan pada Semiloka Agenda Strategis Penelitian dan Pengembangan Lintas Sektoral di Bidang HAM, Kementerian Hukum dan Hak Asasi Manusia RI Balitbang HAM, pada tanggal 7 April 2010 di Wiltop Hotel Jambi, Jurnal Ilmu Hukum, hlm. [Online]. Available: https://media.neliti.com/media/publications/43259ID-integrasi-standar-perlindungan-penghormatan-danpemenuhan-ham-dalam-tugas-dan-fu.pdf. Accesed: March 2, 2020.

[17] Ini Daftar 270 Daerah Gelar Pilkada 2020. [Online]. Available: https://mediaindonesia.com/read/detail/243074-ini-daftar-270daerah-gelar-pilkada-2020. Accesed: May, 6, 2020.

[18] Peraturan Pemerintah Pengganti Undang-Undang Nomor 2 Tahun 2020 tentang Perubahan Ketiga Atas Undang-Undang Nomor 1 Tahun 2015 Tentang Penetapan Peraturan Pemerintah Pengganti Undang-Undang Nomor 1 Tahun 2014 Tentang Pemilihan Gubernur, Bupati, dan Walikota Menjadi UndangUndang, Lembaran Negara Republik Indonesia Tahun 2020 Nomor 128, Tambahan Lembaran Negara Republik Indonesia Nomor 6512.

[19] Putusan Mahkmah Konstitusi Nomor 14-17/PUU-V/2007, bertanggal 11 Desember 2007.

[20] Putusan Mahkmah Konstitusi Nomor 4/PUU-VII/2009, bertanggal 24 Maret 2009.

[21] Putusan Mahkmah Konstitusi Nomor 120/PUU-VII/2009, bertanggal 20 April 2010.

[22] Atika Nur Kusumaningtyas, Female Local Leaders in Local Oligarchy Network, Jurnal Penelitian Politik, Volume 14 No. 2 Desember 2017, pp. 241.

[23] Aisyah Saipuddin, Pasang Surut Hubungan Sipil-Militer Dalam Perpolitikan Pakistan, Jurnal Indpendence, Th. 1, Vol. 1, Januari-April 2013, pp. 64.

[24] Putusan Mahkmah Konstitusi Nomor 71/PUU-XIV/2016, 
bertanggal 19 Juli 2017.

[25] Putusan Mahkmah Konstitusi Nomor 56/PUU-XVII/2019, bertanggal 11 Desember 2019.

[26] Undang-Undang Nomor 42 Tahun 2008 tentang Pemilihan Umum Presiden dan Wakil Presiden, Lembaran Negara Republik Indonesia Tahun 2008 Nomor 176, Tambahan Lembaran Negara Republik Indonesia Nomor 4924

[28] mbahan Lembaran Negara Republik Indonesia Nomor 5898.
[27] Undang-Undang Nomor 10 Tahun 2016 tentang Perubahan Kedua Atas Undang- Undang Nomor 1 Tahun 2015 Tentang Penetapan Peraturan Pemerintah Pengganti Undang-Undang Nomor 1 Tahun 2014 Tentang Pemilihan Gubernur, Bupati, dan Walikota Menjadi Undang-Undang, Lembaran Negara Republik Indonesia
2016

Nomor

130 , 